\title{
ANALISIS FINANSIAL DAN EKONOMI PEMBANGUNAN HUTAN TANAMAN DIPTEROKARPA DENGAN TEKNIK SILIN (STUDI KASUS PT. SARI BUMI KUSUMA, KALIMANTAN BARAT)
}

\author{
Financial \& Economics Analysis Of Dipterocarp Forest Plantation Establishment \\ Using Intensive Silviculture Technique \\ (A Case Study at PT. Sari Bumi Kusuma, West Kalimantan Province)
}

Dhany Yuniati

Balai Besar Penelitian Dipterokarpa

J1. A. Wahab Syahrani No. 68 Sempaja

PO BOX 1206, Samarinda

Naskah masuk : 4 Oktober 2010; Naskah diterima : 12 September 2011

\begin{abstract}
Establishing dipterocarp forest plantation using intensive silviculture technique is associated with long term investment. An analysis of financial and economic feasibility is required to identify the benefit for the company, society and sensitify of such investment to various variables including cost and revenue flow. Using interest rate of $6.4 \%$ for financial analysis and $3.21 \%$ for economic analysis this study analysed dipterocarp forest plantation using intensive silviculture technique at PT. Sari Bumi Kusuma (SBK) in West Kalimantan. Financial analysis shows that using four assessment scenarios, the establishment of dipterocarp forest plantation at PT. SBK is feasible by three scenarios, while the other of which the revenue is from cutting planting line is infeasible. Economic analysis concludes that the establishment of dipterocarp forest plantation is feasible by all scenarios. The highest value of both financial and economic analysis is shown by a scenario of which the revenue is from cutting preparation, planting line and cutting between planting line. The calculation shows that the NPV is Rp. 3,274,809,355,927 the BCR is 2.02 and the IRR is 19\% for financial analysis and the NPV is Rp. 11,484,650,969,273 the BCR is 3.77 and the IRR is $108 \%$ for economic analysis. Financial sensitivity analysis shows a scenario in which revenue from trees cutting on the planting line is not strong against yield decline by $15 \%$ and $30 \%$. While a calculation scenario in which revenue from trees cutting on both planting line and in between line is not strong against yield decline by 30\% but it is still strong enough against yield decline by 15\%. Economic sensitivity analysis indicates that by decreasing productions by 30\%, the establishment of dipterocarp forest plantation still gives benefit widely for society.
\end{abstract}

Keywords: Financial analysis, economic analysis, dipterocarp forest plantation, intensive silviculture

\begin{abstract}
ABSTRAK
Pembangunan hutan tanaman dipterokarpa dengan teknik SILIN berkaitan dengan investasi dalam jangka waktu pengusahaan yang panjang. Diperlukan analisis kelayakan finansial dan ekonomi untuk mengetahui manfaat bagi perusahaan dan masyarakat secara luas serta analisis sensitivitas untuk mengetahui kepekaan pembangunan hutan tanaman dipterokarpa terhadap berbagai kemungkinan dan perubahan pada arus biaya atau pendapatan. Mengacu kepada suku bunga sebesar 6,4\%, untuk analisis finansial dan 4,04\% untuk analisis ekonomi penelitian ini menganalisa kelayakan dari pembangunan hutan tanaman dipterokarpa dengan teknik SILIN di PT. Sari Bumi Kusuma (PT. SBK). Hasil analisis finansial menunjukkan bahwa dari empat skenario penilaian, tiga diantaranya secara finansial pembangunan hutan tanaman dipterokarpa di PT. SBK layak untuk diusahakan sedangkan satu skenario dimana pendapatan yang diperoleh dari tebangan di jalur tanam tidak layak untuk diusahakan. Sedangkan dari hasil analisis ekonomi pembangunan hutan tanaman dipterokarpa layak untuk diusahakan dari semua skenario pendapatan yang ada. Nilai yang paling tinggi baik dari hasil analisis finansial maupun ekonomi
\end{abstract}


ditunjukkan oleh skenario dimana pendapatan diperoleh dari tebangan persiapan, jalur tanam dan jalur antara dengan nilai NPV Rp. 3.274.809.355.926, BCR 2.02 dan IRR 19\% untuk analisis finansial dan NPV Rp.11.484.650.969.272, BCR 3.77 dan IRR 108\% untuk analisis ekonomi. Hasil analisis sensitivitas finansial menunjukkan skenario perhitungan dimana pendapatan yang diperoleh dari tebangan di jalur tanam tidak kuat menghadapi penurunan hasil sebanyak 15\% dan 30\%. Sedangkan skenario perhitungan dimana pendapatan yang diperoleh dari tebangan di jalur tanam dan jalur antara tidak kuat menghadapi penurunan hasil sebanyak 30\% tetapi masih cukup kuat menghadapi penurunan hasil sebanyak $15 \%$. Hasil analisis sensitivitas ekonomi menunjukkan bahwa penurunan hasil sebanyak 30\%, pembangunan hutan tanaman dipterokarpaceae tetap memberikan manfaat bagi masyarakat secara luas.

\section{Kata kunci : Analisis finansial, analisis ekonomi, hutan tanaman dipterokarpa, SILIN}

\section{PENDAHULUAN}

Dewasa ini permintaan kayu mencapai 75,9 juta $\mathrm{m}^{3} \mathrm{RWE}$, sementara itu jumlah pasokan hanya mencapai 24,2 juta $\mathrm{m}^{3}$ (Anonim, 2006), sehingga terjadi kesenjangan pasokan kayu sebesar 51,7 juta $\mathrm{m}^{3}$. Pasokan kayu tersebut berasal dari hutan alam $\left(5,7\right.$ juta $\left.^{3}\right)$, HTI $\left(12,8\right.$ juta $\left.\mathrm{m}^{3}\right)$, hutan tanaman Perhutani $\left(0,8\right.$ juta $\left.\mathrm{m}^{3}\right)$, hutan/kebun rakyat $\left(1,3\right.$ juta $\left.\mathrm{m}^{3}\right)$ dan areal konversi $(3,6$ juta $\mathrm{m}^{3}$ ) (Anonim, 2006). Dari data tersebut terlihat bahwa hutan alam masih merupakan andalan pasokan kayu disamping dari HTI. Sementara itu hutan alam yang ada sebagian besar dalam kondisi terdegradasi sehingga produktivitas hutan alam tropis kayu komersial rata-rata yang dicapai saat ini hanya sekitar $0,5-1,5 \mathrm{~m}^{3} / \mathrm{ha} / \mathrm{th}$ walaupun pada dasawarsa 70-an rata-rata produksi kayu komersial hutan alam tropis bisa mencapai $60-70 \mathrm{~m}^{3} / \mathrm{ha}$ (Soekotjo, 2009).

Peningkatkan produktivitas hutan salah satunya dengan melaksanakan pembangunan hutan tanaman yang prospektif, sehat dan lestari. Salah satu upayanya adalah dengan menerapakan sistim silvikultur intensif (SILIN) dalam rangka pembangunan hutan tanaman jenis-jenis dipterokarpa. SILIN muncul dilatarbelakangi oleh kecenderungan kerusakan hutan alam yang terus berlangsung dan peningkatan kebutuhan akan produk hasil hutan untuk mendukung kehidupan umat manusia (Soekotjo, 2009).

SILIN adalah teknik silvikultur yang memadukan tiga pilar utama silvikultur dalam kegiatan pembinaan hutannya yakni pemuliaan pohon, manipulasi lingkungan dan pengendalian hama dan penyakit terpadu (Soekotjo, 2007). Tujuan umum program SILIN dalam regim TPTII (Tebang Pilih Tanam Indonesia Intensif) adalah membangun hutan tanaman diantara hutan alam bekas tebangan (LOA). Tujuan khususnya lebih ditekankan pada kemampuan IUPHHK dalam membangun hutan tanaman operasional berskala komersial beserta tanaman pendukungnya yang mampu meningkatkan produktivitas dan kualitas produk dari rotasi ke rotasi berikutnya secara dinamis (Soekotjo, 2009). SILIN yang pada awalnya merupakan TPTJ (Tebang Pilih Tanam Jalur) yang dilaksanakan oleh PT. Sari Bumi Kusuma dan PT Erna Juliawati menginspirasi para pakar perguruan tinggi untuk menyempurnakan teknik silvikulturnya terutama dalam penggunaan bibit unggul, teknik manipulasi lingkungan dan pengendalian hama penyakit. Selanjutnya teknik silvikultur dalam TPTJ ini disebut dengan nama lain Tebang Pilih Tanam Indonesia Intensif (TPTII) atau Silvikultur Intensif (SILIN) berdasarkan Keputusan Direktur Jenderal Bina Produksi Kehutanan Nomor SK.226/VI-BPHA/ 2005.

Pembangunan hutan tanaman dipterokarpa dengan teknik Silvikultur Intensif (SILIN) menerapkan kegiatan pembinaan hutan yang berbeda dengan kegiatan pembinaan hutan dalam teknik silvikultur yang lainnya. Kegiatan pembinaan hutan yang intensif pada awal pembangunan hutan tanaman memberikan implikasi pembiayaan lebih besar yang diperlukan dalam rangka peningkatan produktivitas dan kualitas tanaman.

Dalam membangun hutan tanaman operasional perlu mengikuti langkah baku yang lazim dilakukan di kehutanan yang dimulai dari penataan areal kerja (PAK), inventarisasi tegakan sebelum dilakukan penebangan (ITSDP), pembukaan wilayah hutan $(\mathrm{PWH})$, penebangan, persiapan lahan penanaman, persiapan bibit, pembangunan tanaman dan perawatan (Soekotjo, 2009).

Dalam melakukan pemanenan (pemungutan hasil) terkait dengan program SILIN ini ada 3 (tiga) kegiatan pemungutan hasil (penebangan) sebagai sumber pendapatan bagi perusahaan yakni (Anonim, 2009) : 
1. Tebang habis di jalur tanam (penebangan di jalur tanam)

2. Tebang pilih (diameter $40 \mathrm{~cm}$ up) di jalur antara (penebangan di jalur antara)

3. Diawal sebelum pembangunan SILIN terdapat potensi kayu dimana di seluruh areal yang akan dilakukan program SILIN diameter $40 \mathrm{~cm}$ up boleh ditebang (tebangan persiapan). Hal ini sesuai dengan hak IUPHHK yang tercantum dalam SK Penunjukan IUPHHK sebagai Pelaksana SILIN.

Hasil yang diharapkan dari SILIN adalah pohon-pohon berdiameter reratanya $50 \mathrm{~cm}$ dalam kurun waktu maksimal 30 tahun, sehingga standing stock $400 \mathrm{~m}^{3} / \mathrm{ha}$. (Soekotjo, 2009). Apabila kebutuhan kayu disesuaikan dengan hasil tebangan tahun 1990 yaitu sebesar 28 juta $\mathrm{m}^{3}$ pertahun maka kebutuhan tersebut cukup disediakan dari hutan tanaman seluas 100.000 ha/tahun selama 30 tahun.

Pembangunan hutan tanaman dipterokarpa merupakan kegiatan investasi terhadap sumberdaya dan memiliki jangka waktu pengusahaan yang panjang. Sumberdaya yang dialokasikan dalam pembangunan hutan tanaman dipterokarpa antara lain lahan, dana, SDM dan teknologi (Soemitro, 2005). Hal ini meningkatkan resiko terhadap kegiatan investasi yang dilakukan disamping beberapa ketidakpastian yang terjadi dalam pembangunan hutan tanaman yang berkaitan dengan faktor alam seperti banjir, hama dan penyakit, kebakaran dan lain-lain.

Penilaian kegiatan pembangunan hutan tanaman dipterokarpa dengan teknik SILIN pada penelitian ini dilakukan melalui pendekatan nilai finansial (nilai privat) dan nilai ekonomi (nilai sosial). Analisis finansial melihat suatu proyek atau kegiatan dari sudut pandang individu pemilik, sehingga dalam menilai manfaat maupun biaya hanya dari sudut pandang individu atau swasta yang mempunyai kepentingan secara langsung dalam proyek tersebut (Gray, 1985). Menurut Warsito (1995) aspek finansial adalah aspek yang berkenaan dengan kepentingan pengusahaan dimana kegiatan pengusahaan dianggap layak apabila investasi yang ditanamkan bisa memberikan keuntungan positif kepada pemilik modal. Suatu perhitungan dikatakan analisis ekonomi atau perhitungan sosial bila yang berkepentingan langsung dalam benefit dan biaya adalah pemerintah atau masyarakat secara keseluruhan. Nilai dari setiap barang/produk, faktor atau sumberdaya yang akan digunakan atau dihasilkan dinilai berdasarkan kontribusinya terhadap kemakmuran negara (Gray, 1985).

Kegiatan pembangunan hutan tanaman Dipterocarpaceae mempunyai jangka waktu pengusahaan yang panjang. Oleh karenanya Fillius (1992) menganggap faktor waktu menjadi perhatian dalam penilaian terhadap biaya dan pendapatan yang tidak begitu saja dapat diperbandingkan. Oleh karena itu digunakan tingkat suku bunga diskonto (discount rate) sebagai pembandingnya. Menurut Soemitro (1997) dasar utama discount rate adalah bahwa individu atau masyarakat yang menghargai nilai sekarang lebih tinggi dibandingkan dengan nilai yang akan datang dan masalah ketidakpastian terhadap peristiwa yang akan datang menyebabkan nilai sekarang lebih dihargai. Apabila biaya dan pendapatan dari tahun ke tahun selama investasi telah disesuaikan dengan nilai saat ini (present value) maka dapat diambil keputusan apakah suatu investasi ditolak atau diterima.

Menurut Gray (1985) kelayakan finansial dan ekonomi suatu kegiatan ditunjukkan oleh nilai NPV (Net Present Value), B/C ratio (BenefitCost Ratio) atau IRR (Internal Rate of Return). Nilai NPV, B/C ratio dan IRR sesungguhnya saling berhubungan. Suatu kegiatan dikatakan layak secara finansial (menguntungkan bagi perusahaan) bila nilai NPV positif. Bila NPV positif artinya $\mathrm{B} / \mathrm{C}$ ratio lebih besar dari satu dan nilai IRR lebih besar dari tingkat suku bunga diskonto (discount rate) yang dipergunakan dalam perhitungan nilai NPV sehingga salah satu dari ketiga nilai tersebut dapat dipergunakan untuk mengambil keputusan apakah suatu kegiatan akan menguntungkan (layak) atau tidak secara finansial.

Analisis sensitivitas dilakukan untuk melihat pengaruh perubahan-perubahan parameter dalam aspek finansial terhadap keputusan yang diambil. Menurut Gregersen (1979) proyekproyek kehutanan terdapat beberapa ketidakpastian yang mungkin penting berkaitan dengan faktor alam seperti banjir, penyakit, faktor teknologi yang berhubungan dengan proses produksi termasuk juga sistem silvikultur, faktor finansial dan ekonomi yang berkaitan dengan nilai asumsi input dan output dan faktor manusia berhubungan dengan tenaga kerja, kemampuan memperkirakan kejadian-kejadian mendatang mencakup penaksiran volume kayu, keadaan pasar dan sebagainya. Sedangkan menurut Warsito (1986) analisis sensitivitas dilakukan untuk menguji kekuatan proyek terhadap kemungkinan-kemungkinan dan ter- 
jadinya perubahan pada arus biaya atau pendapatan. Lebih lanjut menurut Warsito (1986) variabel yang dianggap paling peka dalam pembentukan komponen biaya maupun pendapatan adalah kemungkinan perubahan produksi dan perubahan tingkat suku bunga. Dengan adanya ramalan perubahan pada komponenkomponen tersebut dapat dilihat efek adanya perubahan-perubahan pada indikator keberhasilan proyek yang digunakan.

Penelitian ini bertujuan untuk mengetahui kelayakan finansial dan ekonomi serta sensitivitas pembangunan hutan tanaman dipterokarpa dengan teknik SILIN terhadap berbagai kemungkinan dan perubahan pada arus biaya atau pendapatan yang terjadi.

\section{METODE PENELITIAN}

\section{A. Kondisi Umum Lokasi Penelitian}

Berdasarkan SK Menteri Kehutanan No. 201/Kpts-II/1998 tanggal 27 Februari 1998 luas areal kerja PT. Sari Bumi Kusuma seluruhnya adalah 208.300 ha, yang terdiri dari Blok S. Seruyan seluas 146.700 ha dan Blok S. Delang seluas 60.700 ha.

Berdasarkan posisi geografis, lokasi penelitian terletak di areal PT. Sari Bumi Kusuma Blok S. Seruyan yang berada diantara $00^{\circ} 36^{\prime}$ $01^{\circ} 10^{\prime}$ Lintang Selatan dan $111^{\circ} 39^{\prime}-112^{\circ} 25^{\prime}$ Bujur Timur.
Secara administratif pemerintahan, Blok S. Seruyan masuk dalam Kec. Seruyan Hulu Kabupaten Seruyan dan Kecamatan Katingan Hulu Kabupaten Katingan, Provinsi Kalimantan Tengah.

\section{B. Waktu Penelitian}

Penelitian dilakukan selama 3 bulan dari bulan September sampai dengan Nopember 2008.

\section{Sumber dan Analisa Data}

1. Data primer yang diperoleh melalui pengukuran langsung di lapangan yang meliputi data pengukuran prestasi kerja kegiatan pengadaan bibit, penyiapan lahan, pemeliharaan, penanaman

2. Data sekunder yang tercatat yang meliputi data kegiatan dan biaya di bidang perencanaan, persemaian, pembukaan wilayah hutan, penyiapan lahan, penanaman, pemeliharaan, investasi dan pemeliharaan bangunan, investasi dan pemeliharaan sarana dan prasarana, gaji dan upah karyawan, penelitian dan pengembangan, pendidikan dan pelatihan, pemanenan, upah tenaga kerja tidak terdidik, suku bunga deposito berjangka 1 tahun, laju inflasi, laju PDRB dan UMR propinsi Kalimantan Barat.

3. Penelitian dimulai dengan mengumpulkan input dan output dalam satuan $\mathrm{Rp} / \mathrm{ha}$. Dari data input dan output kemudian dicari nilainya untuk menaksir biaya dan manfaat.

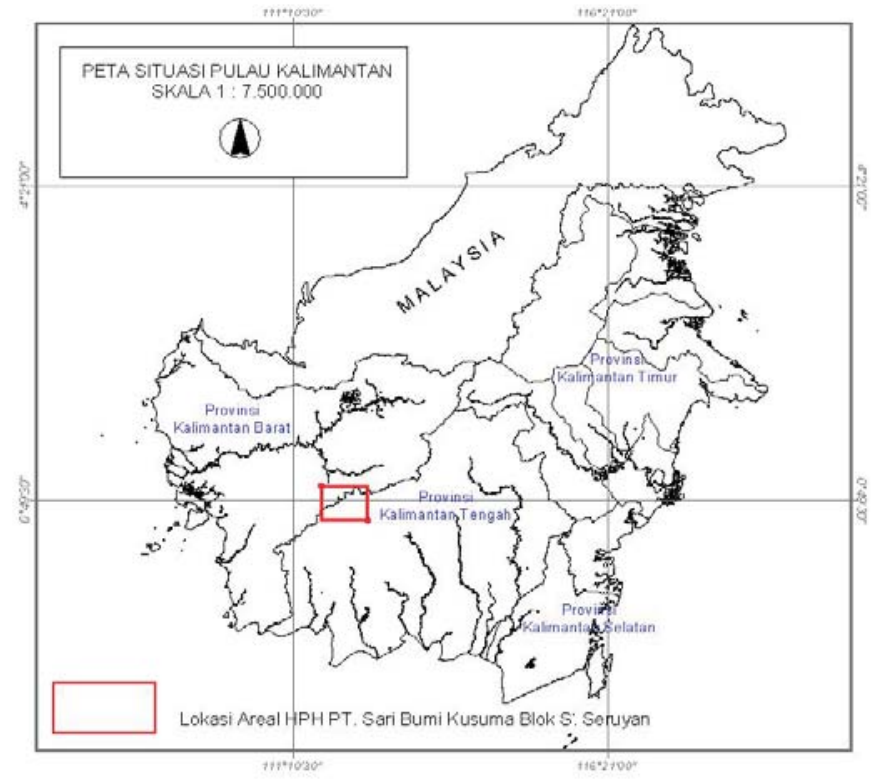

Gambar 1. (Figure 1.) Peta Lokasi Penelitian (Research Area Map) 
Diperlukan suatu penyesuaian nilai terhadap biaya dan manfaat agar dapat diperbandingkan karena nilai uang dapat berubah dari waktu kewaktu. Biaya dan manfaat dinilai pada kondisi saat ini dengan menggunakan faktor penimbang yang disebut discount factor. Untuk analisis finansial sebagai diskon faktor digunakan tingkat suku bunga yang diperoleh dari rata-rata suku bunga riil yang merupakan selisih antara suku bunga perbankan umum nasional dengan laju inflasi selama 10 tahun terakhir tanpa menyertakan tahun 1998 karena pada tahun tersebut terjadi inflasi besar-besaran sehingga tidak mencerminkan performa perekonomian yang normal.

$$
r=\frac{(i \quad f)}{(1 \quad f)}
$$

Dimana $r=$ suku bunga riil (dalam satu tahun)

$\mathrm{i}=$ suku bunga deposito berjangka 1 tahun bank umum

$$
\mathrm{f}=\text { laju inflasi. }
$$

Sedangkan dalam analisis ekonomi suku bunga yang digunakan sebagai diskon faktor didekati dengan tingkat laju pertumbuhan Produk Domestik Bruto (PDRB) menurut provinsi tempat penelitian dilakukan yang dalam hal ini adalah provinsi Kalimantan Barat.

Ukuran tentang layak tidaknya kegiatan dilaksanakan didapatkan dengan digunakan suatu ukuran yang disebut kriteria investasi yang meliputi :

a. NPV (Net Present Value)

$$
\begin{aligned}
\mathrm{NPV} & ={ }_{t_{0}}^{n} \frac{B t}{(1 \mathrm{i})^{t}}-{ }_{t_{0}}^{n} \frac{C t}{(1 \mathrm{i})^{t}}={ }_{t_{0}}^{n} \frac{B t C t}{(1 \quad i)^{t}} \\
\mathrm{~B}= & \text { Manfaat (Benefit) } \\
\mathrm{C}= & \text { Biaya (Cost) } \\
\mathrm{t}= & \text { Waktu (time) } \\
\mathrm{i}= & \text { Tingkat suku bunga diskonto (discount } \\
& \text { rate) }
\end{aligned}
$$

\section{b. BCR (Benefit Cost Ratio)}

$$
\mathrm{BCR}=\frac{{ }_{t 0}^{n} \frac{B t}{(1 i)^{t}}}{{ }_{t 0}^{n} \frac{C t}{(1 i)^{t}}}
$$

c. IRR (Internal Rate of Return).

$\mathrm{IRR}=i+\frac{N P V 1}{N P V 1 \quad N P V 2} *(i 2-i 1)$
Dilakukan juga analisis sensitivitas terhadap penurunan hasil sebesar 15\% dan 30\% dari yang diproyeksikan. Mengembangkan perhitungan pengolahan data dalam suatu lembar kerja (spreadsheet dengan menggunakan Excel) sedemikian sehingga memungkinkan untuk melakukan perhitungan terhadap variabel-variabel yang ada secara fleksibel.

\section{HASIL DAN PEMBAHASAN}

\section{A. Analisis Finansial}

Dalam melakukan analisis finansial di PT. Sari Bumi Kusuma (PT. SBK) perhitungan didasarkan dari empat skenario pendapatan yang akan diperoleh yakni :

a. Pendapatan diperloleh dari tebangan di jalur tanam.

b. Pendapatan diperoleh dari tebangan di jalur tanam dan jalur antara.

c. Pendapatan diperoleh dari tebangan persiapan, jalur tanam dan jalur antara.

d. Pendapatan diperoleh dari tebangan persiapan dan jalur tanam.

Analisis finansial merupakan analisis dipandang dari sudut pengusaha dalam hal ini pemilik IUPHHK untuk mengetahui penilaian finansial terhadap kegiatan pembangunan hutan tanaman dipterokarpacea dengan teknik SILIN. Dalam melakukan analisis finansial di PT. SBK ada beberapa asumsi yang dipakai yakni :

1. Besar upah per HOK adalah Rp 42.075,-

2. Suku bunga analisis finansial yang digunakan sebesar 6,4\% (merupakan suku bunga riil yakni rata-rata selisih antara suku bunga nominal dengan laju inflasi selama 10 tahun terakhir)

3. Jarak tanam dalam jalur $2,5 \mathrm{~m}$ dan jarak antar jalur $20 \mathrm{~m}$ sehingga jumlah tanaman per hektar 200 batang

4. Panjang daur pengusahaan 25 tahun

5. Potensi rata-rata persiapan $57,93 \mathrm{~m}^{3}$

6. Potensi rata-rata tebangan dari jalur tanam pada akhir daur $298,08 \mathrm{~m}^{3}$

7. Potensi rata-rata tebangan dari jalur antara pada akhir daur $122,52 \mathrm{~m}^{3}$

8. Harga kayu meranti per $\mathrm{m}^{3}$ dalam kondisi berdiri (stumpage value) Rp 664.700,-

Dari hasil analisis finansial diperoleh hasil sebagai berikut :

a. Rekap hasil analisis finansial, pendapatan diperoleh dari jalur tanam 
Tabel(Table) 1. Rekap hasil analisis finansial, dimana pendapatan diperoleh dari tebangan di jalur tanam di PT. SBK (Financial analysis cashflow recapitulation of PT. SBK, revenue from the cutting of planting line)

\begin{tabular}{|r|r|}
\hline Jumlah Biaya (Rp) & 9.664 .103 .488 .410 \\
\hline Jumlah Pendapatan (Rp) & 25.057 .186 .115 .616 \\
\hline Pendapatan Bruto (Rp) & 15.393 .082 .627 .206 \\
\hline Tingkat diskon & $6,4 \%$ \\
\hline Jumlah biaya terdiskon (Rp) & 3.207 .293 .783 .102 \\
\hline Jumlah pendapatan terdiskon (Rp) & 2.784 .237 .296 .686 \\
\hline Pendapatan netto (Rp) & -423.056 .486 .416 \\
\hline IRR & $5,6 \%$ \\
\hline NPV (Rp) & -423.056 .486 .416 \\
\hline BCR & 0,8681 \\
\hline Titik BEP & \\
\hline
\end{tabular}

Sumber(Source): Cashflow analisis finansial (Financial analysis of cashflow)

b. Rekap hasil analisis finansial, pendapatan diperoleh dari jalur tanam dan jalur antara

Tabel(Table) 2. Rekap hasil analisis finansial, dimana pendapatan diperoleh dari tebangan di jalur tanam dan di jalur antara di PT. SBK (Financial analysis cashflow recapitulation of PT SBK, revenue from cutting of planting line and cutting between planting line)

\begin{tabular}{|r|r|}
\hline Jumlah Biaya (Rp) & 9.664 .103 .488 .410 \\
\hline Jumlah Pendapatan (Rp) & 35.356 .456 .254 .120 \\
\hline Pendapatan Bruto (Rp) & 25.692 .352 .765 .710 \\
\hline Tingkat diskon & $6,4 \%$ \\
\hline Jumlah biaya terdiskon (Rp) & 3.207 .293 .783 .101 \\
\hline Jumlah pendapatan terdiskon (Rp) & 3.928 .644 .011 .629 \\
\hline Pendapatan netto (Rp) & 721.350 .228 .527 \\
\hline IRR & $7,4 \%$ \\
\hline NPV (Rp) & 721.350 .228 .527 \\
\hline BCR & 1,22 \\
\hline Titik BEP & Tahun ke 40 \\
\hline
\end{tabular}

Sumber (Source) : Cashflow analisis finansial (Financial analysis of cashflow)

c. Rekap hasil analisis finansial, pendapatan diperoleh dari tebangan persiapan jalur tanam dan jalur antara

Dari hasil analisis finansial di atas terlihat bahwa skenario penilaian dimana pendapatan yang hanya diperoleh tebangan di jalur tanam saja, tidak layak diusahakan. Sedangkan tiga skenario perhitungan yang lain secara finansial layak diusahakan. Hal ini dapat dilihat dari nilai NPV yang positif, BCR lebih besar dari satu dan IRR lebih tinggi dari tingkat suku bunga diskonto yang digunakan $(6,4 \%)$. Hal ini menunjukkan bahwa hasil tebangan yang berasal dari jalur tanam saja tidak cukup untuk membiayai operasional perusahaan sehingga harus ada hasil
Tabel (Table) 3. Rekap hasil analisis finansial, dimana pendapatan diperoleh dari tebangan persiapan, di jalur tanam dan di jalur antara di PT. SBK. (Financial analysis cashflow recapitulation of $P T$ $S B K$, revenue from cutting preparation, cutting of planting line and cutting between planting line)

\begin{tabular}{|r|r|}
\hline Jumlah Biaya (Rp) & 9.664 .103 .488 .410 \\
\hline Jumlah Pendapatan (Rp) & 40.226 .165 .029 .206 \\
\hline Pendapatan Bruto (Rp) & 30.562 .061 .540 .796 \\
\hline Tingkat diskon & $6,4 \%$ \\
\hline Jumlah biaya terdiskon (Rp) & 3.205 .464 .286 .519 \\
\hline Jumlah pendapatan terdiskon (Rp) & 6.480 .273 .642 .446 \\
\hline Pendapatan netto (Rp) & 3.274 .809 .355 .927 \\
\hline IRR & $19 \%$ \\
\hline NPV (Rp) & 3.274 .809 .355 .927 \\
\hline BCR & 2,02 \\
\hline Titik BEP & Tahun ke 25 \\
\hline
\end{tabular}

Sumber (Source) : Cashflow analisis finansial (financial analysis of cashflow)

d. Rekap hasil analisis finansial, pendapatan diperoleh dari tebangan persiapan dan jalur tanam

Tabel(Table) 4. Rekap hasil analisis finansial, dimana pendapatan diperoleh dari tebangan persiapan dan di jalur tanam di PT. SBK (Financial analysis cashflow recapitulation of $P T S B K$, revenue from cutting preparation and cutting of planting line)

\begin{tabular}{|r|r|}
\hline Jumlah Biaya (Rp) & 9.693 .069 .146 .884 \\
\hline Jumlah Pendapatan (Rp) & 29.926 .894 .890 .702 \\
\hline Pendapatan Bruto (Rp) & 20.233 .825 .743 .818 \\
\hline Tingkat diskon & $6,4 \%$ \\
\hline Jumlah biaya terdiskon (Rp) & 3.252 .695 .812 .905 \\
\hline Jumlah pendapatan terdiskon (Rp) & 5.335 .866 .927 .504 \\
\hline Pendapatan netto (Rp) & 2.083 .171 .114 .598 \\
\hline IRR & $15,50 \%$ \\
\hline NPV (Rp) & 2.083 .171 .114 .598 \\
\hline BCR & 1,64 \\
\hline Titik BEP & Tahun ke 26 \\
\hline
\end{tabular}

Sumber (Source) : Cashflow analisis finansial (Financial analysis of cashflow)

dari tebangan yang lain diantaranya tebangan persiapan dan tebangan di jalur antara.

Mengacu pada Peraturan Menteri Kehutanan No. P. 11/Men-hut-II/2009 tentang Sistem Silvikultur dalam Areal Izin Usaha Pemanfaatan Hasil Hutan Kayu pada Hutan Produksi bahwa daur dan siklus tebangan pada sistem silvikultur TPTJ di hutan tanah kering dilakukan tebang habis pada jalur 3 meter (jalur tanam) dan pada jalur antara dilakukan penebangan pada diameter $40 \mathrm{~cm}$ up. Jika mengacu pada Peraturan Menteri Kehutanan No. P. 11/Menhut-II/2009 maka secara 
finansial layak diusahakan karena pendapatan yang diperoleh dari penebangan di jalur tanam dan jalur antara menghasilkan nilai NPV yang positif, BCR lebih besar dari satu dan IRR lebih tinggi dari tingkat suku bunga diskonto yang digunakan $(6,4 \%)$.

Keuntungan (yang ditunjukkan oleh nilai NPV) terbesar diperoleh dari skenario perhitungan dimana pendapatan diperoleh dari tebangan persiapan, tebangan di jalur tanam dan jalur antara diikuti oleh skenario dimana pendapatan dihasilkan dari tebangan persiapan dan tebangan di jalur tanam dan terakhir dimana pendapatan dihasilkan dari tebangan di jalur tanam dan di jalur antara. Hal ini menunjukkan bahwa hasil awal berupa tebangan persiapan dapat meningkatkan kemampuan perusahaan dalam membangun hutan tanaman. Menurut Elias (2009) bahwa pemegang IUPHHK yang melaksanakan SILIN secara finansial harus jelas dan meyakinkan dimana hal tersebut tercermin dari potensi hutan yakni volume kayu per hektar yang terdapat dalam hutan alam cukup tinggi dan luas sehingga diperkirakan hasil panennya minimal mampu menanggung biaya penanaman SILIN selama 5 (lima) tahun.

Bila dicermati lebih lanjut terlihat bahwa titik BEP paling awal terjadi di tahun ke 25 . Hal ini menunjukkan selama 25 tahun, perusahaan belum memperoleh keuntungan, sehingga dalam hal ini perlu adanya campur tangan dari pemerintah misalnya pinjaman dana dengan bunga rendah yang dikembalikan setelah melakukan pemanenan di jalur tanam. Disamping itu perlu juga insentif pencabutan dana reboisasi untuk tebangan dari jalur tanam untuk meningkatkan kemampuan finansial perusahaan.

\section{B. Analisis Ekonomi}

Analisis ekonomi merupakan analisis dipandang dari sudut pandang masyarakat secara luas. Dalam melakukan analisis ekonomi di PT. SBK beberapa asumsi yang dipakai yakni :

1. Besar upah per HOK adalah Rp 30.000,(sesuai upah tenaga tak terdidik yang bekerja di luar sektor kehutanan, dalam hal ini sektor perkebunan)

2. Suku bunga analisis ekonomi yang digunakan sebesar 4,04\% (sesuai rata-rata laju PDRB prov. Kalimantan Barat lima tahun terakhir)

3. Jarak tanam dalam jalur $2,5 \mathrm{~m}$ dan jarak antar jalur $20 \mathrm{~m}$ sehingga jumlah tanaman per hektar 200 batang

4. Panjang daur pengusahaan 25 tahun
5. Potensi rata-rata tebangan persiapan $24,84 \mathrm{~m}^{3}$

6. Potensi rata-rata tebangan dari jalur tanam pada akhir daur $259,08 \mathrm{~m}^{3}$

7. Potensi rata-rata tebangan dari jalur antara pada akhir daur $159,64 \mathrm{~m}^{3}$

8. Harga kayu meranti per $\mathrm{m}^{3}$ dalam kondisi berdiri (stumpage value) Rp. 891.700,-

Dari hasil analisis ekonomi diperoleh hasil sebagai berikut :

a. Rekap hasil analisis ekonomi, pendapatan diperoleh dari jalur tanam

Tabel(Table) 5. Rekap hasil analisis ekonomi, dimana pendapatan diperoleh dari tebangan di jalur tanam di PT. SBK (Economic analysis cashflow recapitulation of $P T$. $S B K$, revenue from the cutting of planting line)

\begin{tabular}{|r|r|}
\hline Jumlah Biaya & 9.205 .547 .033 .311 \\
\hline Jumlah Pendapatan & 33.614 .401 .774 .176 \\
\hline Pendapatan Bruto & 24.408 .854 .740 .865 \\
\hline Tingkat diskon & $4,04 \%$ \\
\hline Jumlah biaya terdiskon & 4.131 .601 .235 .459 \\
\hline Jumlah pendapatan terdiskon & 8.085 .032 .747 .245 \\
\hline Pendapatan netto & 3.953 .431 .511 .785 \\
\hline IRR & $7,5 \%$ \\
\hline NPV & 3.953 .431 .511 .785 \\
\hline BCR & 1,96 \\
\hline Titik BEP & Tahun ke 33 \\
\hline
\end{tabular}

Sumber(Source): Cashflow analisis ekonomi (Economic analysis of cashflow)

b. Rekap hasil analisis ekonomi, pendapatan diperoleh dari jalur tanam dan jalur antara

Tabel(Table) 6. Rekap hasil analisis ekonomi, dimana pendapatan diperoleh dari tebangan di jalur tanam dan di jalur antara di PT. SBK (Economic analysis cashflow recapitulation of PT SBK, revenue from cutting of planting line and cutting between planting line)

\begin{tabular}{|r|r|}
\hline Jumlah Biaya & 9.205 .547 .033 .311 \\
\hline Jumlah Pendapatan & 47.430 .949 .363 .320 \\
\hline Pendapatan Bruto & 38.225 .402 .330 .009 \\
\hline Tingkat diskon & $4,04 \%$ \\
\hline Jumlah biaya terdiskon & 4.131 .601 .235 .459 \\
\hline Jumlah pendapatan terdiskon & 11.408 .228 .574 .514 \\
\hline Pendapatan netto & 7.276 .627 .339 .055 \\
\hline IRR & $9 \%$ \\
\hline NPV & 7.276 .627 .339 .055 \\
\hline BCR & 2,76 \\
\hline Titik BEP & Tahun ke 30 \\
\hline
\end{tabular}

Sumber(Source): Cashflow analisis ekonomi (Economic analysis of cashflow) 
c. Rekap hasil analisis ekonomi, pendapatan diperoleh dari tebangan RKT (tebangan awal), jalur tanam dan jalur antara

Tabel(Table) 7. Rekap hasil analisis ekonomi, dimana pendapatan diperoleh dari tebangan persiapan, di jalur tanam dan di jalur antara di PT. SBK (Economic analysis cashflow recapitulation of $P T S B K$, revenue from cutting preparation, cutting of planting line and cutting between planting line)

\begin{tabular}{|r|r|}
\hline Jumlah Biaya & 9.093 .847 .214 .999 \\
\hline Jumlah Pendapatan & 53.963 .699 .949 .666 \\
\hline Pendapatan Bruto & 44.869 .852 .734 .667 \\
\hline Tingkat diskon & $4,04 \%$ \\
\hline Jumlah biaya terdiskon & 4.152 .805 .249 .833 \\
\hline Jumlah pendapatan terdiskon & 15.637 .456 .219 .105 \\
\hline Pendapatan netto & 11.484 .650 .969 .273 \\
\hline IRR & $108 \%$ \\
\hline NPV & 11.484 .650 .969 .273 \\
\hline BCR & 3.77 \\
\hline Titik BEP & Tahun ke 2 \\
\hline
\end{tabular}

Sumber(Source): Cashflow analisis ekonomi (Economic analysis of cashflow)

d. Rekap hasil analisis ekonomi, pendapatan diperoleh dari tebangan persiapan dan jalur tanam

Tabel(Table) 8. Rekap hasil analisis ekonomi, dimana pendapatan diperoleh dari tebangan persiapan dan di jalur tanam di PT. SBK (Ecomomic analysis cashflow recapitulation of $P T S B K$, revenue from cutting preparation and cutting of planting line)

\begin{tabular}{|r|r|}
\hline Jumlah Biaya & $9.093 .847 .214,999$ \\
\hline Jumlah Pendapatan & $40,147,152,360,522$ \\
\hline Pendapatan Bruto & $31,053,305,145,523$ \\
\hline Tingkat diskon & $4.04 \%$ \\
\hline Jumlah biaya terdiskon & $4,152,805,249,837$ \\
\hline Jumlah pendapatan terdiskon & $12,314,260,391,836$ \\
\hline Pendapatan netto & $8,161,455,142,003$ \\
\hline IRR & $108 \%$ \\
\hline NPV & $8,161,455,142,003$ \\
\hline BCR & 2.97 \\
\hline Titik BEP & Tahun ke 2 \\
\hline
\end{tabular}

Sumber(Source): Cashflow analisis ekonomi (Economic analysis of cashflow)

Dari hasil analisis ekonomi di atas terlihat bahwa dari empat skenario penilaian, pembangunan hutan tanaman dipterokarpaceae dengan teknik SILIN di PT. SBK layak untuk di laksanakan karena bermanfaat bagi semua pihak. Hal ini dapat dilihat dari nilai NPV yang positif, BCR lebih dari satu dan IRR lebih tinggi dari tingkat suku bunga diskonto yang digunakan $(4,04 \%)$. Kondisi ini memperkuat alasan bahwa harus ada campur tangan dari pihak pemerintah mengingat manfaat pembangunan hutan tanaman bagi masyarakat luas (dampak sosial) begitu besar tetapi perusahaan kurang mampu melaksanakannya mengingat ada satu skenario dari perhitungan yang menunjukkan tidak layak secara finansial tetapi layak secara ekonomi.

Dampak sosial pelaksanaan SILIN sangat besar bagi masyarakat di sekitar hutan. Dalam Yuniati, dkk (2009) disebutkan bahwa pelaksanaan SILIN di PT. Balikpapan Forest Industries mampu menyerap tenaga kerja langsung sebanyak $0,66 \sim 1$ orang/ha karena banyaknya pekerjaan yang bersifat padat karya. Masih menurut Yuniati, dkk (2009) bahwa terdapat manfaat lain yang menguntungkan bagi masyarakat di sekitar perusahaan yakni tersedianya kesempatan untuk bekerja pada kegiatan SILIN. Adanya alternatif untuk ikut bekerja dalam kegiatan SILIN dan juga adanya kegiatan yang intensif di sekitar hutan berimbas pada menurunnya kegiatan illegal logging di kawasan IUPHHK. Adanya kesempatan kerja juga telah mengundang pencari kerja dari daerah lain untuk datang dan ikut bekerja. Hal ini berimbas pada meningkatknya kegiatan ekonomi warga di sekitar perusahaan. Sebagai contoh bermunculan tempat kost dan rumah sewaan baru, warung makan, toko kelontongan dan lain sebagainya yang pada akhirnya juga meningkatkan pendapatan dari masyarakat setempat.

Di samping manfaat sosial terdapat pula manfaat SILIN terhadap keanekaragaman hayati. Menurut Susilo, dkk (2009) SILIN tidak berdampak negatif pada komunitas burung bawah tajuk. Hasil penelitian yang dilakukan oleh Susilo, dkk (2009) menunjukkan bahwa hutan produksi yang dikelola dengan sistem silvikultur intensif lebih baik dalam mendukung kehidupan burung-burung bawah tajuk. Sistem silvikultur intensif juga tidak berdampak negatif pada komunitas serangga kumbang tinja, meskipun populasi kumbang tinja lebih banyak pada hutan TPTI tetapi ternyata hanya dihuni oleh dua species. Sedangkan pada hutan silin meskipun jumlah individu lebih sedikit tetapi dihuni oleh 7 species. 


\section{Analisis Sensitivitas}

Analisis sensitivitas dilakukan untuk menguji kekuatan proyek terhadap kemungkinan-kemungkinan dan terjadinya perubahan terhadap arus biaya dan atau pendapatan. Ketidakpastian yang mungkin penting di sektor kehutanan salah satunya dalam menaksir volume pada akhir daur. Dalam analisis sensitivitas ini akan dicoba apabila hasil produksi kayu turun sebanyak $15 \%$ dan $30 \%$ dari taksiran volume sebelumnya.

a. Nilai NPV, BCR dan IRR finansial dan ekonomi PT. SBK apabila taksiran produksi dari jalur tanam turun sebesar $15 \%$ dan $30 \%$.

Tabel (Table) 9. Rekap hasil analisis sensitivitas finansial dan ekonomi apabila taksiran produksi di jalur tanam turun $15 \%$ dan 30\% di PT. SBK (Financial and economic sensitivity analysis recapitulation if changing in decreasing production in planting line up to $15 \%$ dan 30\%)

\begin{tabular}{|c|r|r|r|r|}
\hline $\begin{array}{c}\text { Penurunan } \\
\text { Hasil }\end{array}$ & \multicolumn{2}{|c|}{$15 \%$} & \multicolumn{2}{c|}{$30 \%$} \\
\hline Nilai & \multicolumn{1}{|c|}{ Finansial } & \multicolumn{1}{c|}{ Ekonomi } & \multicolumn{1}{c|}{ Finansial } & \multicolumn{1}{c|}{ Ekonomi } \\
\hline NPV & -840.692 .080 .918 & 2.740 .676 .599 .699 & -1.258 .327 .675 .421 & 1.527 .921 .687 .612 \\
\hline BCR & 0,74 & 1,66 & 0,61 & 1,37 \\
\hline IRR & $4,8 \%$ & $6,7 \%$ & $3,7 \%$ & $5,7 \%$ \\
\hline
\end{tabular}

Sumber(Source): Cashflow analisis sensitivitas finansial dan ekonomi (Financial and Economic sensitivity analysis of cashflow)

a. Nilai NPV, BCR dan IRR finansial dan ekonomi PT. SBK apabila taksiran produksi dari jalur tanam dan jalur antara turun sebesar $15 \%$ dan $30 \%$

Tabel(Table) 10. Rekap hasil analisis sensitivitas finansial dan ekonomi apabila taksiran produksi di jalur tanam dan di jalur antara turun $30 \%$ di PT. SBK (Financial and economic sensitivity analysis recapitulation if changing in decreasing production in planting line and between planting line up to $15 \%$ dan $30 \%$ )

\begin{tabular}{|r|r|r|r|r|}
\hline $\begin{array}{c}\text { Penurunan } \\
\text { Hasil }\end{array}$ & \multicolumn{2}{|c|}{$15 \%$} & \multicolumn{2}{c|}{$30 \%$} \\
\hline Nilai & \multicolumn{1}{|c|}{ Finansial } & \multicolumn{1}{c|}{ Ekonomi } & \multicolumn{1}{c|}{ Finansial } & \multicolumn{1}{c|}{ Ekonomi } \\
\hline NPV & 132.053 .626 .783 & 5.565 .393 .052 .877 & -457.242 .974 .962 & 3.854 .158 .766 .700 \\
\hline BCR & 1,04 & 2,35 & 0,86 & 1,93 \\
\hline IRR & $6,6 \%$ & $8,4 \%$ & $5,6 \%$ & $7,4 \%$ \\
\hline
\end{tabular}

Sumber(Source): Cashflow analisis sensitivitas finansial dan ekonomi (Financial and Economic sensitivity analysis of cashflow)

b. Nilai NPV, BCR dan IRR finansial dan ekonomi PT. SBK apabila taksiran produksi dari tebangan persiapan, jalur tanam dan jalur antara turun sebesar $15 \%$ dan $30 \%$

Tabel(Table) 11. Rekap hasil analisis sensitivitas finansial dan ekonomi apabila taksiran produksi tebangan persiapan, jalur tanaman dan jalur antara turun 30\% di PT. SBK (Financial and economic sensitivity analysis recapitulation if changing in decreasing production in cutting preparation, planting line and between planting line up to $15 \%$ dan $30 \%$ )

\begin{tabular}{|c|r|r|r|r|}
\hline $\begin{array}{c}\text { Penurunan } \\
\text { Hasil }\end{array}$ & \multicolumn{2}{|c|}{$15 \%$} & \multicolumn{2}{c|}{$30 \%$} \\
\hline Nilai & \multicolumn{1}{|c|}{ Finansial } & Ekonomi & \multicolumn{1}{c|}{ Finansial } & \multicolumn{1}{c|}{ Ekonomi } \\
\hline NPV & 2.255 .536 .783 .174 & 3.139 .032 .536 .407 & 1.283 .495 .736 .807 & 6.793 .414 .103 .541 \\
\hline BCR & 1,69 & 3,20 & 1,39 & 2,64 \\
\hline IRR & $12,9 \%$ & $39 \%$ & $9,9 \%$ & $17,5 \%$ \\
\hline
\end{tabular}

Sumber(Source): Cashflow analisis sensitivitas finansial dan ekonomi (Financial and Economic sensitivity analysis of cashflow) 
d. Nilai NPV, BCR dan IRR finansial dan ekonomi PT. SBK apabila taksiran produksi dari tebangan persiapan dan jalur tanam turun sebesar $15 \%$ dan $30 \%$

Tabel(Table) 12. Rekap hasil analisis sensitivitas finansial dan ekonomi apabila taksiran produksi tebangan persiapan dan jalur tanam turun 30\% di PT. SBK (Financial and economic sensitivity analysis recapitulation if changing in decreasing production in cutting preparation and planting line up to $15 \%$ dan $30 \%$ )

\begin{tabular}{|c|r|r|r|r|}
\hline $\begin{array}{c}\text { Penurunan } \\
\text { Hasil }\end{array}$ & \multicolumn{2}{|c|}{$15 \%$} & \multicolumn{2}{c|}{$30 \%$} \\
\hline Nilai & \multicolumn{1}{|c|}{ Finansial } & \multicolumn{1}{c|}{ Ekonomi } & Finansial & \multicolumn{1}{c|}{ Ekonomi } \\
\hline NPV & 1.282 .791 .075 .473 & 6.314 .316 .083 .228 & 482.411 .036 .347 & 4.467 .177 .024 .453 \\
\hline BCR & 1,39 & 2,52 & 1,15 & 2,08 \\
\hline IRR & $11 \%$ & $39 \%$ & $8 \%$ & $16 \%$ \\
\hline
\end{tabular}

Sumber(Source): Cashflow analisis sensitivitas finansial dan ekonomi (Financial and Economic sensitivity analysis of cashflow)

Dari hasil analisis sensitivitas finansial menunjukkan skenario perhitungan dimana pendapatan yang diperoleh dari tebangan di jalur tanam tidak kuat menghadapi penurunan hasil sebanyak $15 \%$ dan $30 \%$. Sedangkan skenario perhitungan dimana pendapatan yang diperoleh dari tebangan di jalur tanam dan jalur antara tidak kuat menghadapi penurunan hasil sebanyak 30\% tetapi masih cukup kuat menghadapi penurunan hasil sebanyak $15 \%$. Dua skenario yang lain masih cukup kuat menghadapi penurunan hasil sebanyak $30 \%$.

Dari hasil analisis sensitivitas ekonomi menunjukkan bahwa penurunan hasil sampai $30 \%$, pembangunan hutan tanaman dipterokarpa dengan teknik SILIN di PT. SBK tetap memberikan manfaat kepada masyarakat secara luas.

\section{KESIMPULAN DAN SARAN}

\section{A. Kesimpulan}

1. Dari empat skenario penilaian, tiga diantaranya secara finansial pembangunan hutan tanaman dipterokarpa di PT. SBK layak untuk diusahakan sedangkan satu skenario dimana pendapatan yang diperoleh dari tebangan di jalur tanam tidak layak untuk diusahakan.

2. Dari empat skenario penilaian secara ekonomi pembangunan hutan tanaman dipterokarpa dengan teknik di PT. SBK layak untuk dilakukan karena bermanfaat bagi masyarakat secara luas

3. Analisis sensitivitas finansial menunjukkan skenario perhitungan dimana pendapatan yang diperoleh dari tebangan di jalur tanam tidak kuat menghadapi penurunan hasil sebanyak $15 \%$ dan $30 \%$. Sedangkan skenario perhitungan dimana pendapatan yang diperoleh dari tebangan di jalur tanam dan jalur antara tidak kuat menghadapi penurunan hasil sebanyak 30\% tetapi masih cukup kuat menghadapi penurunan hasil sebanyak $15 \%$.

4. Hasil analisis sensitivitas ekonomi menunjukkan bahwa penurunan hasil sebanyak $30 \%$, pembangunan hutan tanaman dipterokarpa tetap memberikan manfaat bagi masyarakat secara luas.

5. Hasil yang berupa tebangan persiapan merupakan modal awal bagi IUPHHK yang akan membangun hutan tanaman dipterokarpa dan sangat berpengaruh terhadap kelayakan fnansial dan ekonomi.

\section{B. Saran}

1. IUPHHK yang tidak memiliki modal berupa tebangan persiapan dengan potensi yang memadai perlu memperoleh akses terhadap permodalan dengan bunga yang rendah.

2. Memperpendek rantai birokrasi sehingga akan menghemat biaya operasional yang pada akhirnya akan meningkatkan kemampuan finansial bagi IUPHHK yang bersangkutan.

3. Insentif penghapusan Dana Reboisasi untuk hasil kayu dari jalur tanam untuk meningkatkan profit sehingga meningkat pula kemampuan finansial bagi IUPHHK.

\section{DAFTAR PUSTAKA}

Anonim, 2006. Statistik Kehutanan Indonesia Tahun 2006. Departemen Kehutanan. Jakarta 
Anonim, 2009. Peraturan Menteri Kehutanan No. P. 11/Menhut-II/2009 Tentang Sistem Silvikultur dalam Areal Izin Usaha Pemanfaatan Hasil Hutan Kayu pada Hutan Produksi. Departemen Kehutanan. Jakarta

Anonim, 2009. Peraturan Direktorat Jenderal BPK No. P.9/VI-BPHA/2009 Tentang Pedoman Pelaksanaan Sistem Silvikultur Tebang Pilih Tanam Jalur (TPTJ). Departemen Kehutanan. Jakarta

Elias, 2009. Sistem dan Teknik Silvikultur Pengelolaan Hutan Produksi di Indonesia. Modul yang disampaikan pada diklat WAS-GANIS Pemanenan Hutan Produksi. Bogor.

Fillius, A. M. 1992. Invesment Analysis in Forest Management; Principes and Applications. Agricultural University Departement of Forestry. Wageningean.

Gray, C., L. Karlina dan Kadariah. 1985. Pengantar Evaluasi Proyek. Edisi Pertama PT Gramedia. Jakarta.

Gregersen, H. dan C. Arnold. 1979. Economyc Analysis of Forestry Project. FAO, Roma.

Susilo, A. Ngatiman. Indra A. Armansyah dan Murtopo B. 2009. Dampak Sistem Silvikultur Intensif (Silin) terhadap Keragaman Hayati. Laporan Tahunan
2009 (Tidak dipublikasikan). Balai Besar Penelitian Dipterokarpa, Samarinda.

Soekotjo, 2007. Pengalaman dari uji jenis dipterocarpa umur 4,5 tahun di PT. Sari Bumi Kusuma Kalteng. Makalah seminar pembangunan hutan tanaman dipterokarpa 4-5 September 2007. Balai Besar Penelitian Dipterokarpa, Samarinda.

Soekotjo, 2009. Teknik Silvikultur Intensif (SILIN). Gadjah Mada University Press. Yogyakarta.

Soemitro, A. 2005. Analisis Kebijakan Revitalisasi Hutan di Indonesia. Debut Press. Yogyakarta.

Warsito, S. P. 1986. Kapita selekta ekonomi kehutanan. Fakultas Kehutanan Universitas Gadjah Mada, Yogyakarta.

Warsito, S. P.1995. Analisis finansial dan ekonomi dalam penyusunan perencanaan pengusahaan hutan. Fakultas Kehutanan Universitas Gadjah Mada. Yogyakarta.

Yuniati, D. \& Lydia, S. 2009. Biaya Investasi Langsung, Prestasi Kerja dan Penyerapan Tenaga Kerja Langsung pada Kegiatan SILIN (Studi Kasus di PT. Balikpapan Forest Industries). Info Teknis Dipterokarpa Vol. 3 No. 1. Balai Besar Penelitian Dipterokarpa, Samarinda. 